\title{
DIALEKTBRUK OG SPRÅKLEG KLIMA I NOREG
}

\author{
MARTIN SKJEKKELAND
}

Det er nokså vanleg at folk i Noreg nyttar dialekten sin når dei snakkar med andre menneske. Det språklege klimaet i landet vårt er prega av toleranse for dialektbruk, meir enn i dei fleste land i Europa. Me høyrer dialektar rundt oss heile tida, og bruk av dialekt er godtatt på dei fleste samfunnsområda, i skulane, på universiteta, i TV og radio, i poesi og popptekstar osb. I norske aviser er det ikkje sjeldan me kan lesa om dialektar, og om at dialekten der eller der er i endring. Truleg er Noreg det einaste landet i Europa der reportasjar av dette slaget er godt avisstoff. Når folk frå ulike delar av det langstrekte landet vårt blir intervjua i radio og på fjernsyn, snakkar dei fleste sin lokale dialekt. Jamvel på talarstolen i Stortinget er bruk av dialekt heilt vanleg, noko som også er eit særnorsk fenomen (jf. Venås, 1992: 342 og Jahr, 1997: 365).

\section{Historisk forklaring på dialektbruk i det norske språksamfunnet}

Det er fleire grunnar til at nordmenn er så tolerante for språkleg variasjon, og at dialektane har høg prestisje i det norske samfunnet. Éin viktig grunn er å finna i norsk nasjonsbygging på 1800-talet. Etter lausrivinga frå Danmark i 1814 var ein på jakt etter alt det norske i kulturen vår, i musikken, målarkunsten og i språket. Nasjonalromantikarane på denne tida interesserte seg sterkt for historia. Kunstnarar, politikarar og embetsmenn søkte etter det ekte norske. Dei leita i folkekulturen, i historia og i språket. Ideen til dette hadde dei i opplysningstida med grunnlag 
i dyrkinga av det „,naturlege”. Same prosessen hadde ein sett i andre europeiske land, i fransk opplysningstid og i tysk nasjonalromantikk. Det var bonden som blei den fremste beraren av det norske. Den norske bonden blei eit ideal fordi han levde i pakt med naturen, langt vekk frå byane, som var påverka av kulturen i Danmark og i utlandet elles (jf. Jahr, 2015: 19).

Språket blei særleg viktig i bygginga av den nye nasjonen. Store delar av overklassa tidleg på 1800-talet kjende det som smertefullt at me etter lausrivinga frå Danmark ikkje hadde eit nasjonalt skriftmål. Hos oss hadde det norrøne skriftspråket blitt borte og var erstatta med dansk skrift frå midt på 1400-talet. Dei norske dialektane var likevel lite påverka av hopehavet med Danmark. Det blei difor naturleg å gå til dialektane for å finna att det norske språket! I dialektane fann dei linjene tilbake til ,eit opphavleg språk”. Dialektane i Bygde-Noreg viste restar av „gullalderspråket” på same måten som ein i folkediktinga fann restar av gullalderlitteraturen. I dialektane (folkemålet) såg ein ei klar linje tilbake til det stolte gammalnorske opphavsmålet.

\section{Eit nytt landsmål bygt på dialektane}

Ivar Aasen fekk midt på 1800-talet i oppgåve å finna ut om det var mogleg å etablera eit norsk skriftspråk som kunne erstatta det danske. I 1842 fekk Aasen stipend frå Vitskapsselskapet i Trondheim, og i tida 1842-46 reiste han rundt i landet og samla inn opplysningar om talemålet i Noreg. Det var eit viktig poeng for Aasen at det nye skriftmålet skulle byggja på alle dialektane. Han sa det slik: „Det er ikke min Hensigt hermed at framhæve nogen enkelt av vore Dialekter; nei, ingen saadan bør være Hovedsprog, men dette skulde være en Sammenligning af, Et Grundlag for dem Alle" (Aasen, 1836). Den overordna ideen for Aasen var at det nye skriftmålet skulle vera norsk. Gjennom sitt store og grundige arbeid skapte Aasen det han kalla Landsmaalet $i$ Norge, det som seinare blei til dagens nynorsk (jf. Jahr, 2015: 19f.). Aasen sitt arbeid med å synleggjera grammatikken og ordtilfanget i norske dialektar, og skapinga av eit skriftmål som bygde på dialektane, var med på å auka vørdnaden for dialektar og dialektbruk i Noreg.

\section{Dialektbruk i klasserommet}

Ein annan svært viktig grunn til at bruk av dialekt er vanleg i det norske språksamfunnet, ligg i historia til det norske skulesystemet. Utover på 1870-talet var det ein del lærarar som prøvde å få elevane til å tala etter mønster av det danske 
skriftmålet. Dei skulle læra å snakka slik det stod i boka - ein leseuttale om har blitt kalla for „klokkardansk”. Denne forma for leseopplæring kom politikarane på Stortinget for øyra, og dei likte det ikkje. Resultatet blei at Stortinget i 1878 gjorde eit vedtak der det heitte: „Undervisningen i Almueskolen bør saavidt mulig meddeles paa Børnenes eget Talemaal" (jf. Jahr, 1997: 368). Denne lovfestinga av at elevane skal få bruka dialekten sin i opplæringssituasjonen, er ganske spesiell, og ho gjeld den dag i dag, sjølv om den språklege formuleringa av lovteksten har endra seg noko opp gjennom tida. Vedtaket i 1878 om at talemålet til elvane skal vera i sentrum i skulen, er truleg den aller viktigaste grunnen til at dei norske dialektane har halde seg så godt som dei har, og at bruk av dialekt har vore vanleg til i dag. Samtidig med at styresmaktene i grannelanda bruka skulesystemet til å ta knekken på dialektane (sjå nedanfor), kom skulen i Noreg til å verka som eit vern av heimemålet til elevane (Omdal, 1999: 6).

\section{Ikkje opplæring i standardnorsk}

Eit resultat av det nemnde stortingsvedtaket om skulemålet i 1878, og tilsvarande formuleringar i grunnskulelova og i den nyare opplaringslova, er at elevane her i landet ikkje får opplæring i bruk av eit norsk standardtalemål, men skal fritt få nytta dialekten sin. Det er ein demokratisk filosofi bak dette at daglegspråket til både born og vaksne er godt nok i alle talespråk-situasjonar (jf. Venås, 1992: 346; Omdal, 1999: 7).

\section{Solidaritet med lokalsamfunnet - og andre grunnar}

Andre forhold som ligg til grunn for at dialektbruk og ikkje standardnorsk har blitt ein del av kvardagen vår, ligg i den språklege solidariteten mange har kjent med språket i sitt lokalsamfunn. Å „knota” (leggja om på språket) har vore lite akseptert i småbyen eller bygda der ein har hatt sin oppvekst (jf. Jahr, 1997: 366).

I tillegg til alle dei faktorane eg alt har vore inne på, som har stimulert dialektbruk, kan ein nemna at Oslo by har aldri vore ein hovudstad som har vore kulturelt og språkleg dominerande på same måten som til dømes København og Stockholm. Historisk sett har ikkje Oslo-målet sett opp ein standard for talemålet utover i landet, slik tilfellet har vore med hovudstadene i grannelanda våre.

Noreg er på ein måte eit språkleg ,annleisland”. Folk er glade over å kunna utfalda seg på dialekten sin. Dialekten blir også av mange rekna som ein del av den norske kulturarven, og er for svært mange ein del av deira personlege identitet. 


\section{Språkleg klima i nabolanda våre, Danmark og Sverige}

I Sverige og Danmark har $\emptyset$ ving i å bruka standardisert talemål (rikssvensk og riksdansk) vore eit viktig ledd i svensk- og danskundervisninga, og der har målet vore å koma bort frå bruk av dialekt. Sverige og Danmark har vist seg som meir «normale» språksamfunn ved at skuleelevane samstundes med skriftspråksopplæringa også blir kjende med eit meir riksspråkleg eller standardspråkleg talespråk (jf. Omdal, 1999: 6). I Sverige får skulestyresmaktene i seinare tid ein stor del av skulda for at dialektane i visse område av landet er på vikande front (jf. Hultgren, 1979). I Danmark er talemålsnormering i skulen ikkje eksplisitt uttrykt i noko regelverk for undervisninga, men blir sett på som naturleg og nærast sjølvsagt av både lærarar og foreldre (Kristiansen, 1990).

Etter kvart som standardtalespråket eller meir regionale varietetar av standardtalespråket har erstatta dialektane både i Danmark og Sverige, er det nå slik at dei mange stadar er borte. Jørn Lund hevdar at det i Danmark er slik at de fleste «taler rigsmål (udviklet på grundlag af københavnsk talesprog i højere sociallag) eller regionalsprog, den egnsbestemte variant af rigsmålet (1993: 32). Lund viser også til at dei fleste danskar nå bur i byområde, og berre eit mindretal på 4-5 prosent av innbyggjarane kan tala dialekt, og dei fleste av desse er tospråklege, og dialekten er for det meste eit «heimespråk» (ibid.). Dialektbruk i dansk blir ofte assosiert ofte med periferi («på landet») og har låg sosial status. Berre i dei vestlige og sørlege delane av Jylland og på Bornholm er dialekten i bruk hos yngre og middelaldrande personar - i tillegg til hos den eldste generasjonen (jf. Vikør, 1993: 46). I Sverige har ikkje tilbakegangen for dialektane vore like sterk som i Danmark. Men dialektane blir av svenskane ofte oppfatta som uforståelege for utanforståande (Vikør, 1993: 191). Dialektane blir også i Sverige sedde på som eit «heimespråk» og «kvardagsspråk». Ute i samfunnet er det rikssvensk som gjeld, med sine regionale variantar, til dømes skånsk. Meir om utviklinga i danske og svenske dialektar, sjå til dømes Bruun (1990), Klemmensen (1995) og Dahlstedt (1978).

\section{Litteratur}

Aasen, I. 1836. „Om vort Skriftsprog”. I: Syn og segn. 1909.

Bruun, T. 1990. „Tilbage til dialekterne!” [Melding av Grethe Rostbøll (red.). Sprog og kvalitet, Modersmål-Selskabets årbog 1990.] Berlingske Tidende 19.12.90.

Dahlstedt, K.-H. 1978. „Dialekt och högspråk i nutidens Sverige, särskilt i Norrland”. I: Zeitler, R. (red.). Det moderna Skandinaviens framväxt (= Symposia Universitatis Upsaliensis Annum Quingentesimum Celebrantis 10). 49-69. Uppsala. (= Kobenhavnstudier i tosprogethed 14). 31-42.

Hultgren, S.O. 1979. „Dialekterna i dagens Sverige - förekomst, attityder och avgränsning gentemot riksspråket”. I: Venås, K. (red.). Dialekt og riksspråk $i$ skulen. Rapport frå eit nordisk symposium på Lysebu 2.-5. april 1979. Oslo: Universitet i Oslo. 35-50. 
Jahr, E.H. 1997. „On the use of dialects in Norway”. I: Ranisch, H. og K. Wynne (red.). Language in time and space. Studies in honour of Wolfgang Viereck on the occasion of his 60th Birthday. Stuttgart: Franz Steiner Verlag. 364-369.

Jahr, E.H. 2015. Språkplanlegging og språkstrid. Utsyn over norsk språkhistorie etter 1814. Oslo: Novus forlag.

Klemmensen, K.M.G. 1995. „Hvor er det dog synd, at dialekterne forsvinder!” Mål og Maele 18.2. 6-10.

Kristiansen, T. 1990. Udtalenormering i skolen. Skitse af en ideologisk bastion. København: Gyldendal.

Lund, J. 1993. „Omformning, udvikling - afvikling? Det danske sprogsamfund i sociolingvistisk fugleperspektiv". I: Standardspråk og dialekt. Seminarer i Oslo 1991 og 1992. [Bergen-Oslo:] Bergens Riksmålsforening og Det Norske Akademi for Sprog og Litteratur. 29-40.

Omdal, H. 1999. „,Språklig mangfold og språklig toleranse”. Språknytt 3.4. 4-11.

Venås, K. 1992. "Dialects and standards in Norway". I: Leuvensteijn, J.A. og J.B. van Berns (red.). Dialects and standard language. Amsterdam: North-Holland. 337-350.

Vikør, L.S. 1993. The Nordic languages. Their status and interrelations (=Nordic Language Secretariat. Publication No. 14). Oslo: Novus. 